THE CASE FOR A CARBON TAX 



\section{The Case for \\ a Carbon Tax}

GETTING PAST OUR HANG-UPS

TO EFFECTIVE CLIMATE POLICY

Shi-Ling Hsu

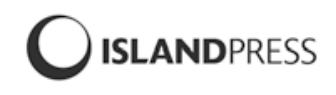

Washington $\mid$ Covelo $\mid$ London 


\section{Copyright (C) 2011 Shi-Ling Hsu}

All rights reserved under International and Pan-American Copyright Conventions. No part of this book may be reproduced in any form or by any means without permission in writing from the publisher: Island Press, 1718 Connecticut Ave., NW, Suite 300 Washington, DC 20009.

ISLAND PRESS is a trademark of the Center for Resource Economics.

\section{Library of Congress Cataloging-in-Publication Data}

\section{Hsu, Shi-Ling.}

The case for a carbon tax : getting past our hang-ups to effective climate policy /

Shi-Ling Hsu. - lst ed.

p. $\mathrm{cm}$.

Includes bibliographical references and index.

ISBN-13: 978-1-59726-531-7 (cloth : alk. paper)

ISBN-10: 1-59726-531-4 (cloth : alk. paper)

ISBN-13: 978-1-59726-533-1 (pbk. : alk. paper)

ISBN-10: 1-59726-533-0 (pbk. : alk. paper) 1. Carbon taxes. 2. Climatic changesGovernment policy. I. Title.

HJ5316.H78 2011

$363.738^{\prime} 746-\mathrm{dc} 23$

2011014901

Printed on recycled, acid-free paper

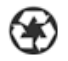

Manufactured in the United States of America

$\begin{array}{llllllllll}10 & 9 & 8 & 7 & 6 & 5 & 4 & 3 & 2 & 1\end{array}$

Keywords: climate change, environmental policy, cap-and-trade, energy subsidies, renewable energy, Kyoto Protocol, greenhouse gas emissions, global warming, environmental economics, Stern Report 


For my children, Katharine and Allen 



\section{O N T E N T S}

Acknowledgments

Chapter 1 Introduction 1

$\begin{array}{lll}\text { Chapter } 2 \text { Climate Change Policy Alternatives } & 13\end{array}$

$\begin{array}{ll}\text { Carbon Taxes } & 15\end{array}$

Command-and-Control Regulation $\quad 17$

Cap-and-Trade 20

Government Subsidies $\quad 23$

Chapter 3 Ten Arguments for a Carbon Tax 25

One: Economic Efficiency 27

Two: Excessive Formation of Capital 41

Three: Non-Interference with Other Regulatory Instruments or Jurisdictions 46

Four: Government Is Better at Reducing "Bads" Than Increasing "Goods" 53

Five: Incentives for Innovation-Price Effects 65

Six: Incentives for Innovation-Price Breadth 77

Seven: Administrability $\quad 84$

Eight: International Coordination 90

Nine: Revenue Raising 101

Ten: Economic Efficiency Revisited: Prices versus

Quantities under Uncertainty 104

$\begin{array}{ll}\text { Conclusion } & 115\end{array}$

$\begin{array}{lll}\text { Chapter } 4 \text { Arguments against a Carbon Tax } & 117\end{array}$

Political Economy Considerations 118

Regressiveness 124

Ineffectiveness $\quad 138$

Crowding Out 143

Conclusion $\quad 145$

$\begin{array}{lll}\text { Chapter } 5 & \text { Carbon Tax Psychology } & 147\end{array}$

The "Do No Harm" Effect 152

The Identifiability Effect 163 
The Endowment Effect 170

Conclusion

Chapter 6 Changing Political Fortunes?

181

Chapter 7 Conclusion

191

Endnotes

195

Index

223 
I tease my wife about things that take longer than she initially thinks they would, but to put up a mirror and consider my own projects, this book is really very typical of the things that I have done with some care: it took much longer than I thought it would. Along the way, I benefited from the comments, advice, support, and input of many people, including Michael Waggoner, Michael Meurer, David Weisbach, Dan Cole, Scott Schang; and from the many fine faculty and students that have attended workshops at Pace Law School, the James E. Rogers College of Law at the University of Arizona, the Florida State University College of Law, the Boston University School of Law, Boston College Law School, and from my friends and colleagues that have listened to me pontificate at meetings of the Midwestern Law and Economics Association and the Society of Environmental Law and Economics. I am also indebted to Island Press's Emily Davis for her editorial support and from three anonymous reviewers who have helped improve this book immensely. I have benefited from and learned much from my research assistant, Oliver Pulleyblank, who will write something much better than this someday. I have also been aided by the institutional support of the University of British Columbia Faculty of Law. Closer to home, I owe a huge debt of gratitude to my parents, who made everything before and after this book possible by crossing the Pacific Ocean to a strange country in which they did not speak the language. On the other side of the generational divide, I am inspired every day to try and do better by my children, Katharine and Allen, who are the real "game-changers." And finally and most of all, to bring this full circle, I owe my wife, Debby- "big time”, as her astute friends have put it-for just putting up with everything. 
